\title{
POL Gene
}

National Cancer Institute

\section{Source}

National Cancer Institute. POL Gene. NCI Thesaurus. Code C16618.

This gene is involved in the replication of the retroviral genome. 